\title{
Effect of Bentonite Addition on Geotechnical Properties of Oil- Contaminated Sandy Soil
}

\author{
Amirhossein Mohammadi ${ }^{1}$, Taghi Ebadi ${ }^{1}$, Mehrdad Ahmadi ${ }^{2}$ \\ 1. Department of Civil \& Environmental Engineering, Amirkabir University of Technology, \\ Tehran, Iran \\ 2. Department of Infrastructure Engineering, University of Melbourne, Melbourne, Victoria, \\ Australia \\ E-mail:a_h_mohammadi@aut.ac.ir
}

Received: 30 August 2018; Accepted: 26 September 2018; Available online: 25 November 2018

\begin{abstract}
Oil and its derivatives not only change the chemical and biological properties of the soils, but also affect their geotechnical properties. Effects of oil contamination on a sandy soil which mixed with bentonite was assessed in terms of compaction, shear strength, and consolidation behavior. The experiments were carried out by polluting dry sandy soil with $2.5,5,7.5,10 \%$ w/w crude oil at different bentonite contents $(0,5,10,15,20 \%$ w/w). Results of compaction tests indicated that at a fixed bentonite content, with increasing crude oil content, the maximum dry density increases, while the optimum water content decreases. Similarly, at a fixed contaminant content, increasing the bentonite content in the soil leads to increase in soil maximum dry density and the optimum moisture content. Moreover, direct shear tests revealed that at a specific bentonite content, higher contamination concentration causes lower internal friction angle. The effect of oil content on the coefficient of consolidation $\left(\mathrm{C}_{\mathrm{v}}\right)$ and void ratio of soils with $0,5,10,15$, and 20 percent bentonite contents was studied. The results of consolidation tests indicated that at a fixed bentonite content $\mathrm{C}_{\mathrm{v}}$ has an overall increasing pattern which is in its maximum amount at $5 \%$ oil content.
\end{abstract}

Keywords: Bentonite; Compaction; Shear strength; Consolidation; Oil contaminated soil; Sand

\section{Introduction}

By increasing the global demand for oil products, the possibility of oil leakage to water and soil would also increase. Oil contamination, mainly occurs during transportation, and leakage from storage tanks or pipelines. Subsequently, soils and groundwater might be contaminated. This problem, in turn, poses many other threats against both environmental and soil properties. Negative impacts of this contamination on the ecosystem are the reason why many researches have been concentrated on soil cleanup from hydrocarbon pollution during recent years. Moreover, a deep knowledge of geotechnical behavior of soil is obtained through many researches which have focused on clayey [1-3], sandy [4], granitic [5, 6], basaltic [7], lateritic [8, 9], etc. In other words, many studies have investigated the effects of oil contamination on geotechnical properties of different soil compositions so far. However, effect of bentonite addition to soil on the geotechnical behavior of the contaminated soil has not been reported amongst former studies.

Bentonite is a kind of clay generated frequently from the alteration of volcanic ash, consisting predominantly of smectite minerals, usually montmorillonite. A fundamental property of bentonite is water absorption. The level of hydration and swelling depends on the type of exchangeable ions contained, with different hydrophilic and solvating power [10]. Addition of bentonite to oil-contaminated soil is proved to enhance the bacterial activity aiming degradation of the contamination [11]. Additionally, the function of bentonite toward oil pollution is reported to be coagulation, adsorption and emulsification [12]. Presence of bentonite in soil presumably introduces some specific geotechnical behavior when subjected to oil contamination. This effect is investigated comprehensively in current study.

Moavenian and Yasrebi [13] investigated the effect of oil contamination on the consolidation properties of clay soils. Results indicate an increase in volume of montmorillonite and decrease in volume of kaolinite with increasing the dielectric constant [13]. Ijimdiya [8] determined the effect of motor oil contamination on the consolidation and strength of lateritic soils. Results show a decrease in coefficient of volume compressibility $\left(\mathrm{m}_{\mathrm{v}}\right)$, coefficient of consolidation $\left(\mathrm{C}_{\mathrm{v}}\right)$ and unconfined compressive strength (UCS) with increasing the motor oil 
content [8]. Talukdav and Saikia [14] investigated the effect of crude oil contamination on the consolidation properties of soil. Coefficient of consolidation $\left(\mathrm{C}_{\mathrm{v}}\right)$ of $\mathrm{CL}$ type of soil was declined considerably with increasing in crude oil contamination. Compression index was studied in this project, but variation in this parameter was not considerable [14]. Nazir [1] investigated the effect of motor oil contamination on Atterberg limits, unconfined compressive strength, coefficient of permeability, and compressibility characteristics of over-consolidated clay. Results indicate that with increasing motor oil, unconfined compressive strength decreased by about $38 \%$ as compared to the control value and the Atterberg limits are decreased and the coefficient of permeability is considerably increased during the first 3 months of contamination. Oil contamination shows minor influence on over-consolidation ratio [1]. Khosravi et al. [2] assessed the effect of petroleum-derived contaminants on the properties of soils. Contaminated samples were prepared by different gas oil contents with kaolinite. Increasing the gas oil content resulted in decreasing compressibility and friction angle and increasing cohesion of kaolinite soils [2].

\section{Material and methods}

\subsection{Reagents and materials}

In this study, crude oil, sand, and bentonite were supplied from Tehran oil refinery, Silica Sand MFG Company, and Mokarrar Composite Company, respectively. The sandy soil was synthesized by mixing equal amounts of two sand types (foundry sand 141 and industrial sand D11). Table 1 shows a brief description of the resulting mixture characteristics. Crude oil specifications are tabulated in Table 2.

Table 1. Composition of the synthesized sandy soil

\begin{tabular}{lllllll}
\hline \multicolumn{7}{c}{ Composition (\%) } \\
\hline $\mathrm{SiO}_{2}$ & $\mathrm{Fe}_{2} \mathrm{O}_{3}$ & $\mathrm{Al}_{2} \mathrm{O}_{3}$ & $\mathrm{~K}_{2} \mathrm{O}$ & $\mathrm{CaO}$ & $\mathrm{MgO}$ & LOI \\
\hline 97.5 & 0.85 & 0.95 & 0.19 & 0.27 & 0.24 & 0.0 \\
\hline
\end{tabular}

Table 2. Specifications of crude oil supplied from Tehran Oil Refinery

\begin{tabular}{cc}
\hline Parameter & Value \\
\hline Specific gravity $\left(15.56^{\circ} \mathrm{C}\right)$ & $0.8597 \mathrm{gr} / \mathrm{cm}^{3}$ \\
Kinematic Viscosity $\left(20^{\circ} \mathrm{C}\right)$ & $11.22 \mathrm{~mm}^{2} / \mathrm{s}$ \\
API & 33.09 \\
Sulphur content & $1.8 \mathrm{Wt} \%$ \\
\hline
\end{tabular}

Moreover, Particle size analysis was performed in case of the soil according to ASTM D422-07 [15]. Figure 1 illustrates the grain size distribution of the soil sample. According to the grain size distribution, values of $\mathrm{D}_{10}, \mathrm{D}_{60}$, and $\mathrm{D}_{30}$ were obtained; consequently, $\mathrm{C}_{\mathrm{u}}$ and $\mathrm{C}_{\mathrm{c}}$ were calculated.

Additionally, the soil was classified by unified soil classification system (USCS) according to ASTM D248711 [16] as SP (poorly-graded sand). ASTM D854-02 [17] was used for obtaining the specific gravity of soil grains. In order to assess the relative density $\left(\mathrm{D}_{\mathrm{r}}\right), \mathrm{e}_{\max }$ and $\mathrm{e}_{\min }$ were obtained through ASTM D4253-06 [18] and ASTM D4254-06 [19], respectively (Table 3). Water content of the soil was analyzed with respect to ASTM D2216-10 [20]. Table 3 holds a list of the soil characteristic parameters.

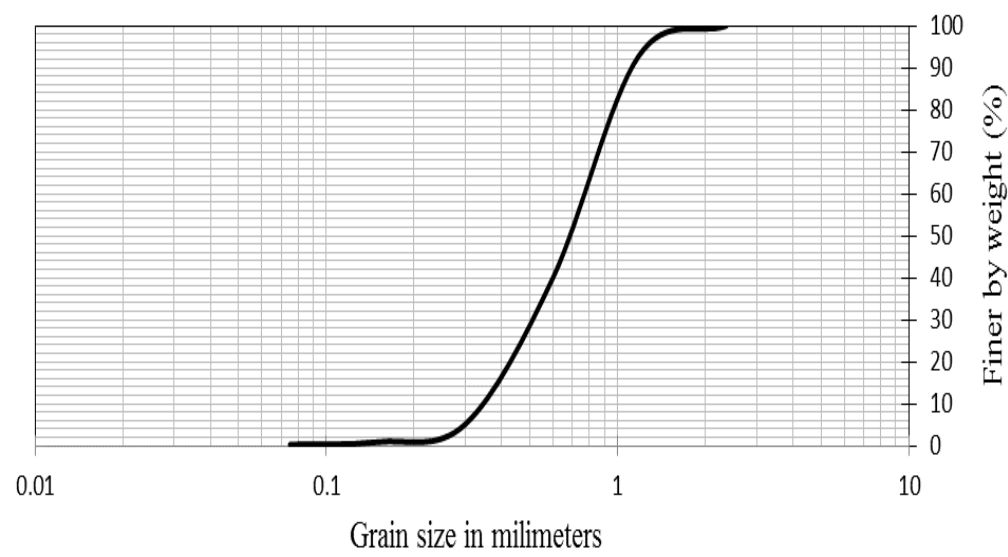

Figure 1. Grain size distribution of the soil sample 
Table 3. Parameters of soil characteristics

\begin{tabular}{ll}
\hline Parameter & Value \\
\hline Soil type $(U S C S)$ & SP \\
$\mathrm{G}_{\mathrm{s}}\left(\mathrm{gr} / \mathrm{cm}^{3}\right)$ & 2.664 \\
$\mathrm{C}_{\mathrm{u}}$ & 2.16 \\
$\mathrm{C}_{\mathrm{c}}$ & 0.89 \\
$\mathrm{w}(\%)$ & 1.13 \\
$\mathrm{D}_{10}(\mathrm{~mm})$ & 0.36 \\
$\mathrm{e}_{\min }$ & 0.62 \\
$\mathrm{e}_{\max }$ & 0.89 \\
$\mathrm{D}_{\mathrm{r}}$ & 48.15 \\
\hline
\end{tabular}

Table 4 carries the results of XRF analysis on bentonite sample. The result shows the possibility of $\mathrm{Mg}^{+2}$ and $\mathrm{Fe}^{+3}$ isomorphic substitution for $\mathrm{Al}^{+3}$ in octahedra within the bentonite.

Table 4. Chemical analysis of bentonite sample

\begin{tabular}{cc}
\hline Compound & $\%$ \\
\hline $\mathrm{SiO}_{2}$ & 61.39 \\
$\mathrm{Al}_{2} \mathrm{O}_{3}$ & 13.07 \\
$\mathrm{Fe}_{2} \mathrm{O}_{3}$ & 2.60 \\
$\mathrm{TiO}_{2}$ & 0.24 \\
$\mathrm{CaO}$ & 4.60 \\
$\mathrm{MgO}$ & 1.71 \\
$\mathrm{Na}_{2} \mathrm{O}$ & 2.92 \\
$\mathrm{~K}_{2} \mathrm{O}$ & 0.62 \\
$\mathrm{~S}$ & 1.63 \\
$\mathrm{MnO}$ & 0.04 \\
$\mathrm{P}_{2} \mathrm{O}_{5}$ & 0.07 \\
\hline \multicolumn{2}{l}{$\mathrm{LOI}=12.15 \%$}
\end{tabular}

\subsection{Sample preparation}

Samples of contaminated soil were synthetically prepared by adding certain amount of crude oil $(0,2.5,5,7.5$, $10 \% \mathrm{w} / \mathrm{w}$ ) to the dry soil. Each sample was incubated for 10 days at room temperature in a two-layered black plastic bag to block sunlight exposure and to enable the possible reaction between soil and oil. Figure 2 shows the prepared samples.

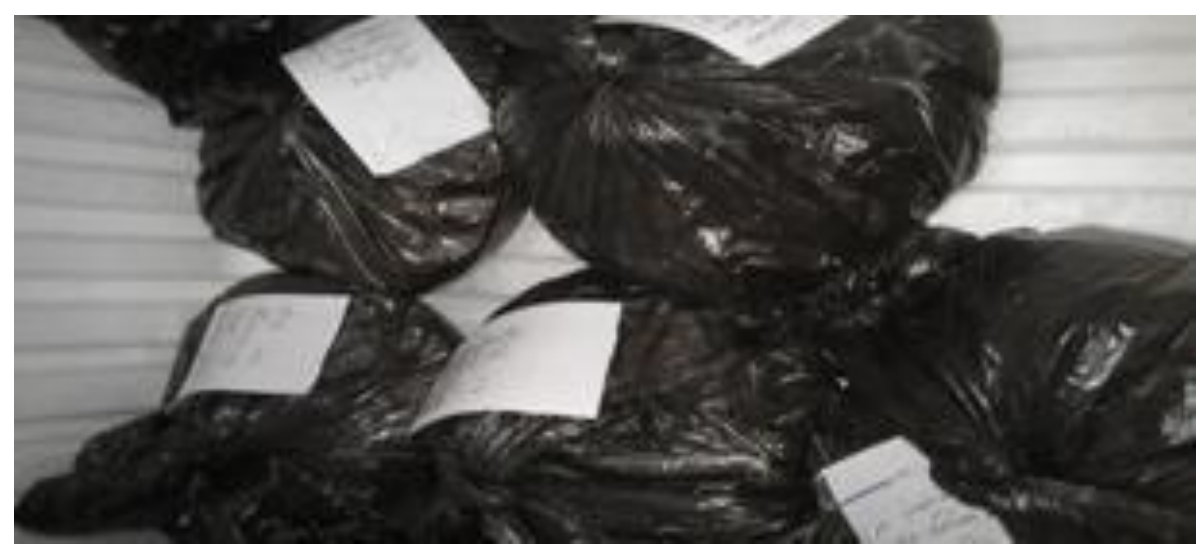

Figure 2. Contaminated soil samples incubated in two-layered black plastic bag

\subsection{Geotechnical tests}

In this research, the testing program included compaction, direct shear, and consolidation tests for understanding the effects of crude oil contamination on geotechnical properties of soil samples. First of all, a base density was found by the compaction tests, in order to prepare appropriate samples for direct shear and consolidation tests. 


\subsubsection{Standard proctor compaction test}

Compaction behavior was evaluated through standard proctor test (ASTM D698-07, [21]) in case of the followings:

i) Pure sand $(0,2.5,5,7.5,10 \% \mathrm{w} / \mathrm{w}$ crude oil contaminated)

ii) Sand plus $0,5,10,15$, and $20 \% \mathrm{w} / \mathrm{w}$ bentonite mixture $(0,2.5,5,7.5,10 \% \mathrm{w} / \mathrm{w}$ crude oil contaminated).

In other words, 25 standard compaction tests were performed.

The maximum dry densities and optimum moisture contents of soil samples were taken as the base values. According to this assumption, all of the samples will be on the dry side of the compaction curve and their differences lies in the various crude oil contents [3].

\subsubsection{Direct shear test}

Direct shear test was carried out aiming to find the effect of oil contamination on strength parameters of soils. The tests were performed according to ASTM D3080 [22] in the following conditions:

i) Pure sand $(0,2.5,5,7.5,10 \% \mathrm{w} / \mathrm{w}$ crude oil contaminated)

ii) Sand plus 5, 10, 15, and 20\% w/w bentonite mixture $(0,2.5,5,7.5,10 \% \mathrm{w} / \mathrm{w}$ crude oil contaminated).

In this part of the experiments, a total number of 75 direct shear tests were performed in a rectangular shear box $(10 \mathrm{~cm} \times 10 \mathrm{~cm})$ under normal stress of 1,2 , and $3 \mathrm{~kg} / \mathrm{cm}^{2}$ (approximately 100, 200, and $300 \mathrm{kPa}$ ) with a shear rate of $1 \mathrm{~mm} / \mathrm{min}$.

\subsubsection{Consolidation test}

Consolidation test is performed to determine the magnitude and rate of decreasing in the volume of soil specimen. This part of tests contains one-dimensional consolidation (consolidation ring with $5 \mathrm{~cm}$ diameter and $1.8 \mathrm{~cm}$ height) test which soil specimen is laterally confined and undergoes to different vertical pressures $(2.5,5$, 10 and $20 \mathrm{kN} / \mathrm{m}^{2}$ ). The tests were performed according to ASTM D2435-11 [23] in the following conditions:

i) Pure sand $(0,2.5,5,7.5,10 \% \mathrm{w} / \mathrm{w}$ crude oil contaminated),

ii) Sand plus 5, 10, 15, and $20 \% \mathrm{w} / \mathrm{w}$ bentonite mixture $(0,2.5,5,7.5,10 \% \mathrm{w} / \mathrm{w}$ crude oil contaminated).

In order to draw consolidation curve (pressure-ratio relationship), 25 consolidation tests were performed. These data are useful in determining coefficient of consolidation and void ratio versus oil content under constant pressures.

\section{Result}

\subsection{Results of geotechnical tests: compaction test}

Results of compaction test on different soil samples are given in Figure 3(a-e). The figures show that, at a specific bentonite content, the maximum dry density of the soil increases with oil content and it is achieved at lower water content. In fact, the soil particles are covered by crude oil, the contaminant acting as a strong lubricating agent which enables higher density at lower water content. The results could also be discussed in a different fashion (Figure 4). As can be seen, at a fixed amount of oil contamination, higher bentonite content leads to a higher value of soil maximum dry density, and the soil needs to absorb more water to reach this value. In other words, bentonite addition to soil increases both the soil maximum dry density and the optimum water content.

\subsection{Results of geotechnical tests: direct shear test}

Figure 5a illustrates the effect of bentonite content on the internal friction angle of the contaminated soil. The results reveal that, by increasing bentonite content of soil mixture, internal friction angle decreases. This trend enhances significantly in higher amounts of oil contamination. Figure $5 \mathrm{~b}$ reflects the very same results but in a different fashion; obviously, higher bentonite content leads to smaller internal friction angle, but less drop in the value for higher oil contents.

Figure 6 demonstrates the effect of bentonite content and crude oil content on cohesion of soils, respectively. According to these figures, cohesion of clean soil sample with $0 \%$ bentonite is close to zero $\left(0.05 \mathrm{~kg} / \mathrm{cm}^{2}\right)$ and it seems probably the apparent cohesion of the sand, whereas the contaminated samples show relatively higher values of cohesion with respect to their composition (i.e. the higher the oil and bentonite content the higher the cohesion value). This behavior could be the result of viscosity and inherent cohesion of oil as well as natural cohesive character of bentonite. In fact, oil is more influential on the cohesion than bentonite when compared at equal bentonite/oil content. 


\subsection{Results of geotechnical tests: consolidation test}

\subsubsection{Effect of crude oil contamination on coefficient of consolidation}

The effect of increasing in oil content on coefficient of consolidation $\left(\mathrm{C}_{\mathrm{v}}\right)$ for soil with $0 \%$ bentonite content is depicted in Figure 7a. The results for other bentonite contents (5\% to 20\%) also are shown in this figure. Based on the experimental results, increase in oil content will result in overall increase in $\mathrm{C}_{\mathrm{v}}$. As can be seen in most of the curves in Figure $7 \mathrm{a}$, the coefficient $\mathrm{C}_{\mathrm{v}}$ has a maximum amount at $5 \%$ oil content. The value of $\mathrm{C}_{\mathrm{v}}$ begins to decline by using oil more than $5 \%$.

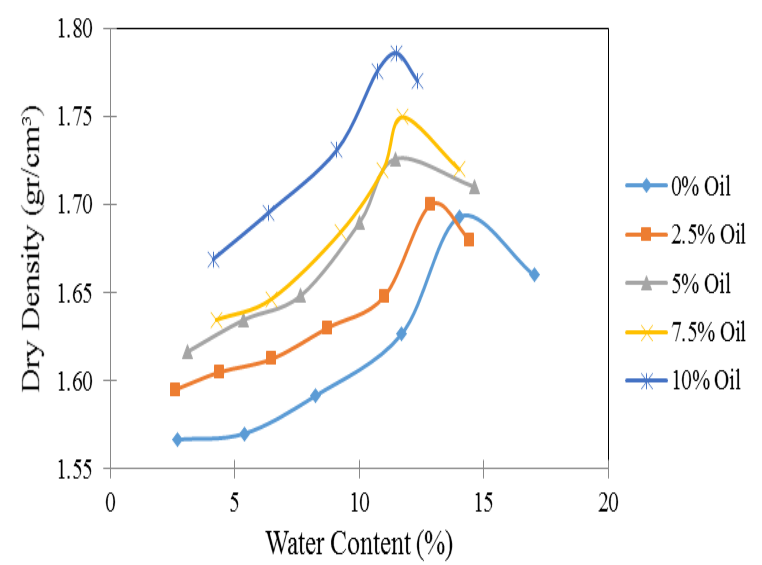

a

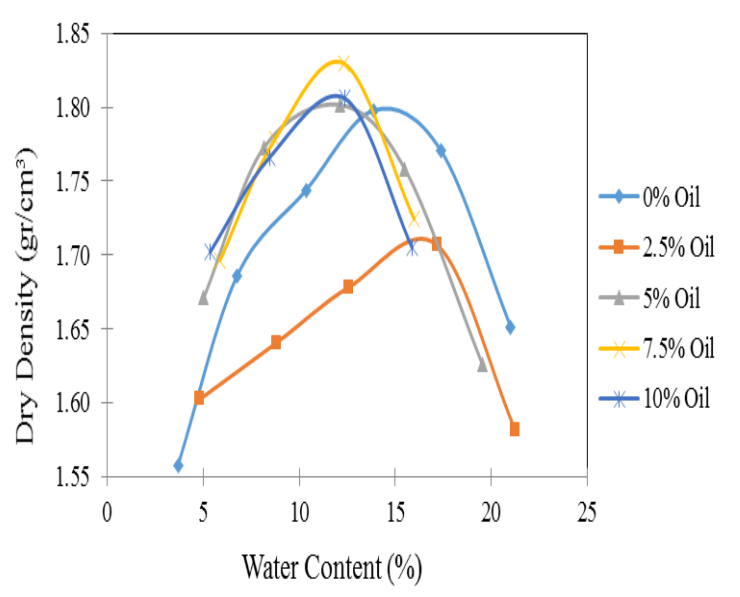

c

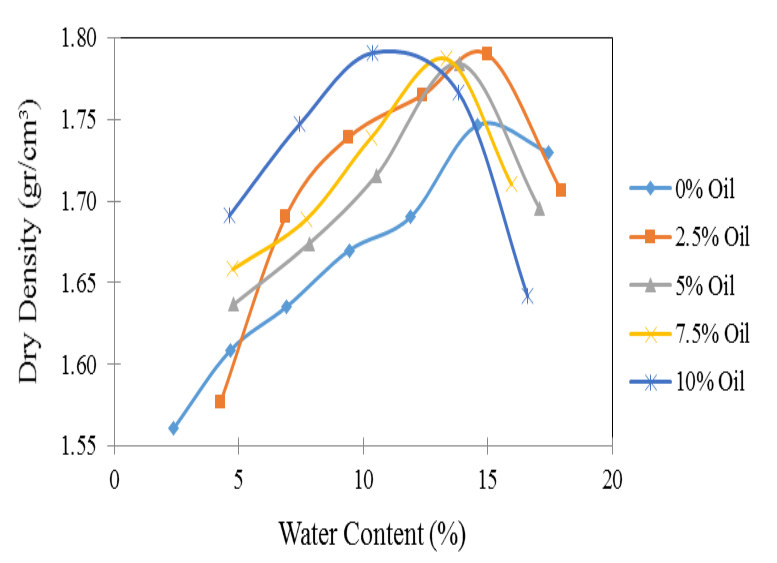

b

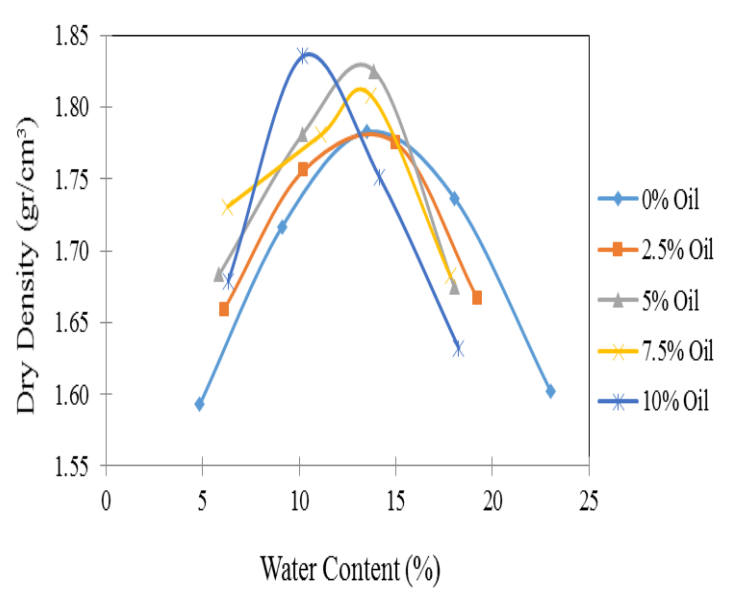

d

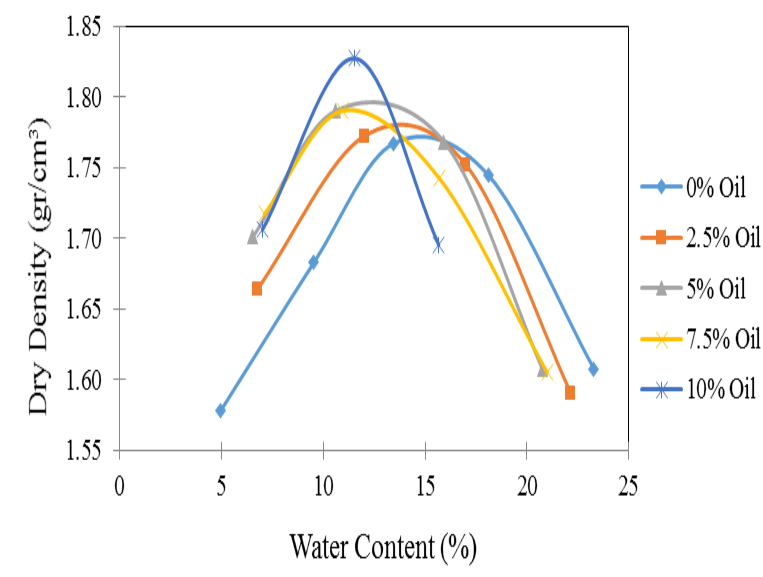

e

Figure 3. Results of compaction test in case of a) $0 \%$, b) $5 \%$, c) $10 \%$, d) $15 \%$, and e) $20 \%$ bentonite addition 


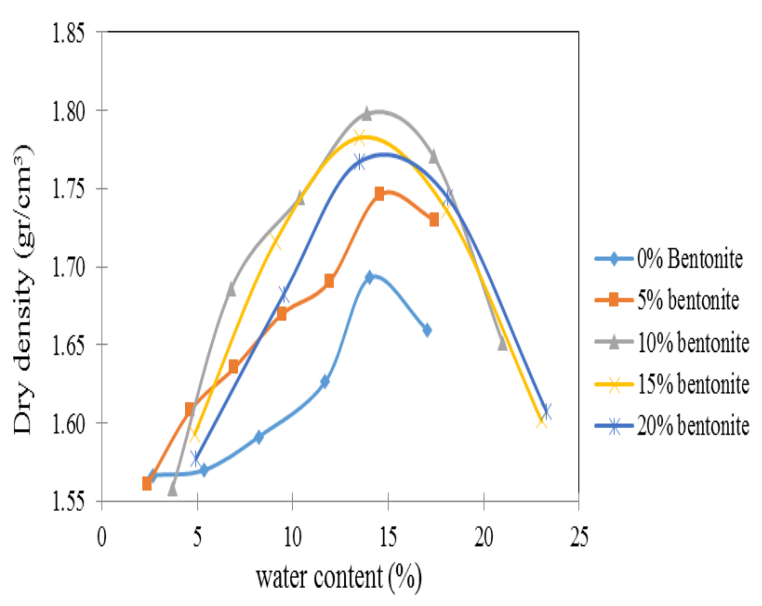

$\mathbf{a}$

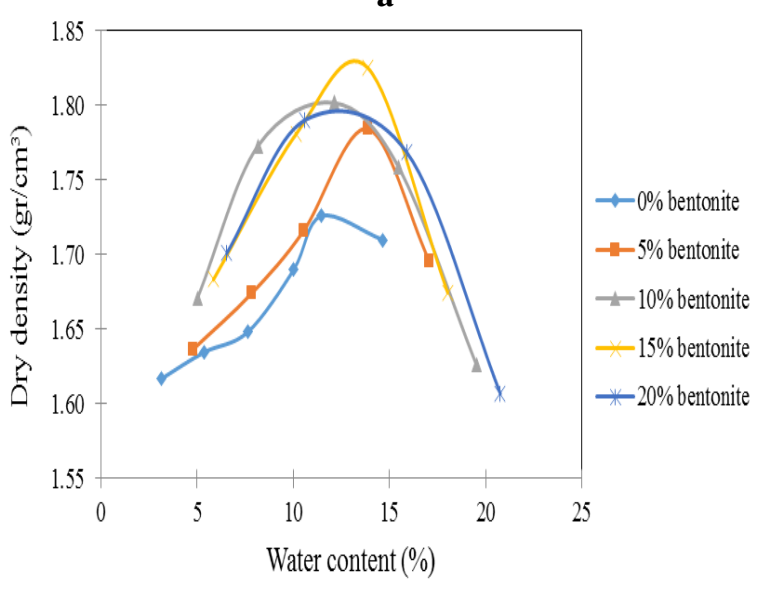

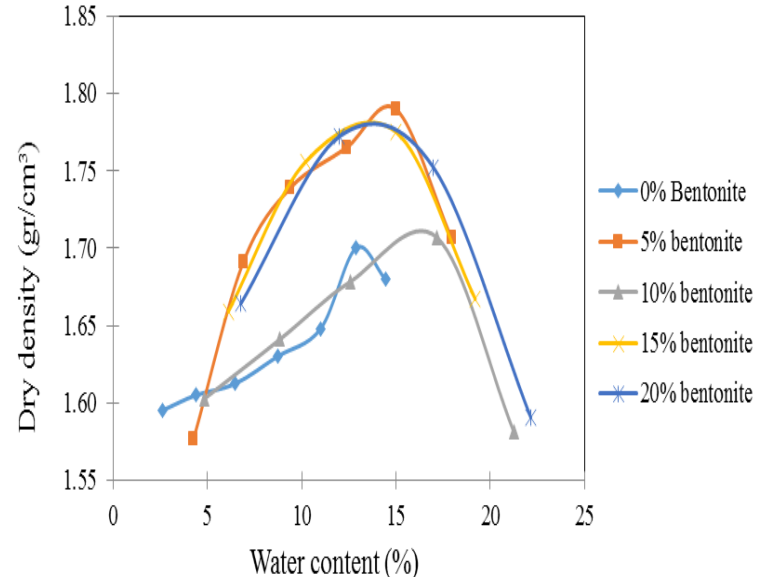

b

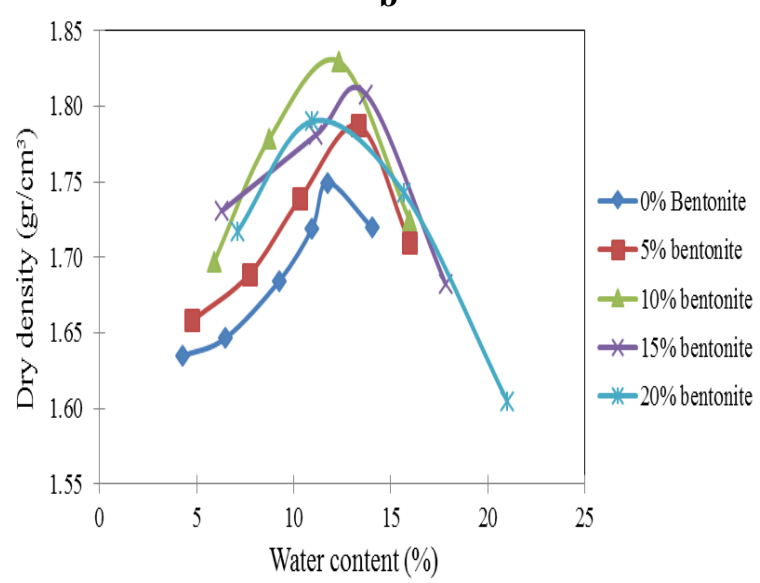

d

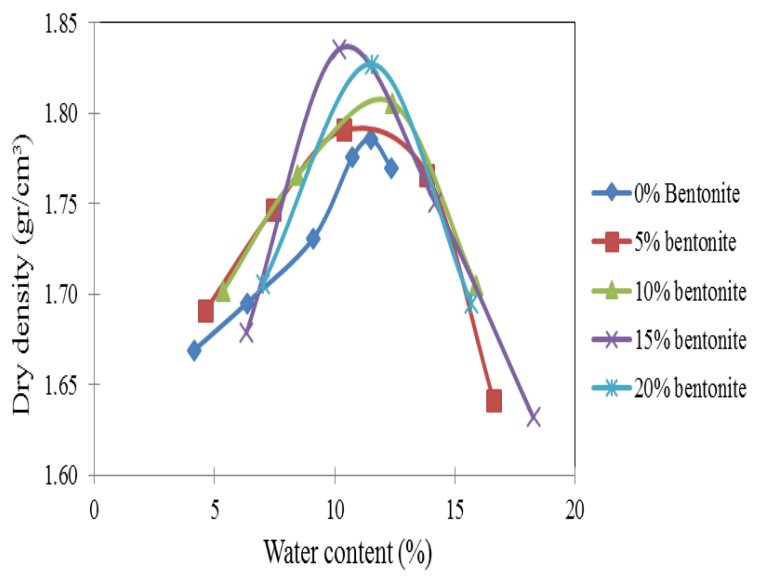

e

Figure 4. Results of compaction test in case of soil with a) $0 \%$, b) $2.5 \%$, c) $5 \%$, d) $7.5 \%$, and e) $10 \%$ oil contamination

Increasing in value of $\mathrm{C}_{\mathrm{v}}$ with higher oil contamination could be due to the initial settlement and derivation of oil from the soil matrix with adding heavier loads during consolidation process. The same results can be seen in [8].

\subsubsection{Effect of crude oil contamination on void ratio}

The effect of oil content on the void ratio of soils with $0,5,10,15$, and 20 percent bentonite contents are illustrated in Figure 8. Experimental results show that void ratio of all contaminated soils (except $20 \%$ bentonite content soil) have increasing pattern below 5\% contamination. This pattern become almost constant after 5\% oil contamination. Void ratio of all soils decreases with increase in pressure. This decrease may be because of more 
compaction which is the result of heavier loads. Soil particles will approach to each other when pressure increases; then void ratio will decrease. In $20 \%$ bentonite content an unusual pattern for void ratio is observed. As an illustration in Figure 8e, void ratio has an almost periodic pattern with increasing in oil content. The same results can be seen in [8].

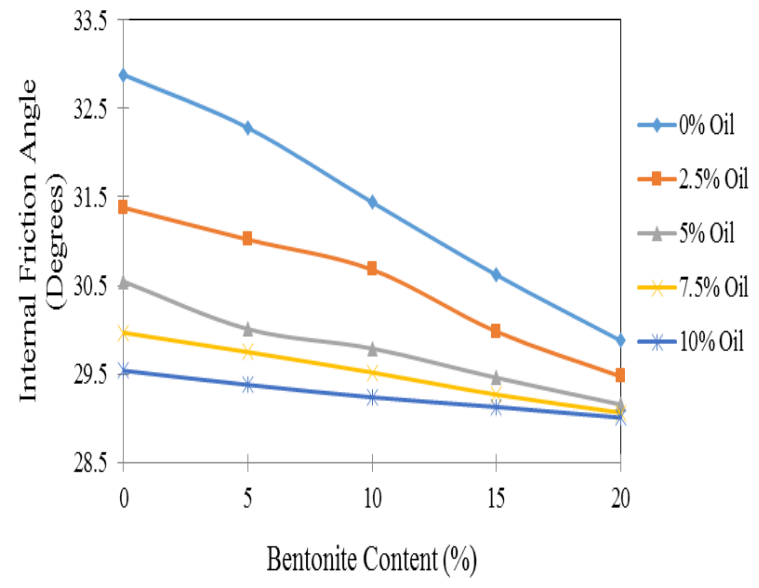

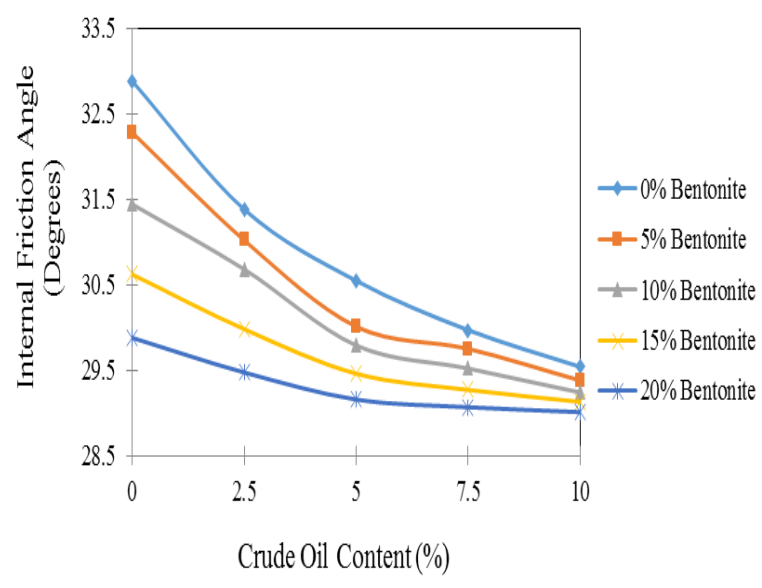

b

Figure 5. Variations of the internal friction angle with a) different levels of oil contamination and b) different bentonite contents

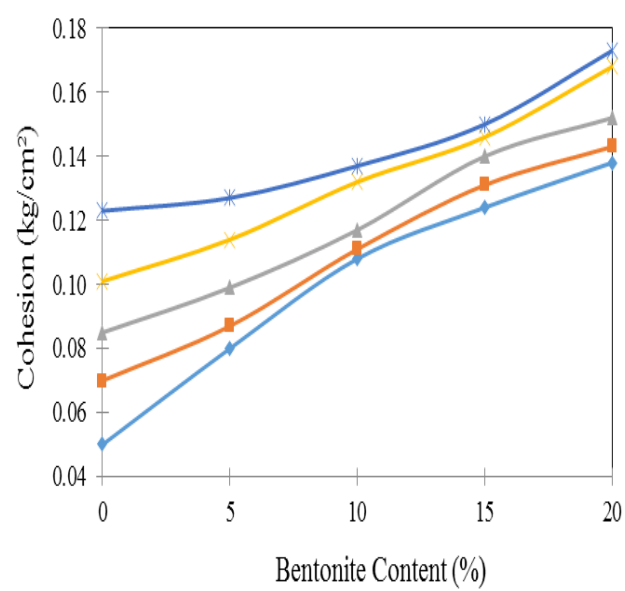

a

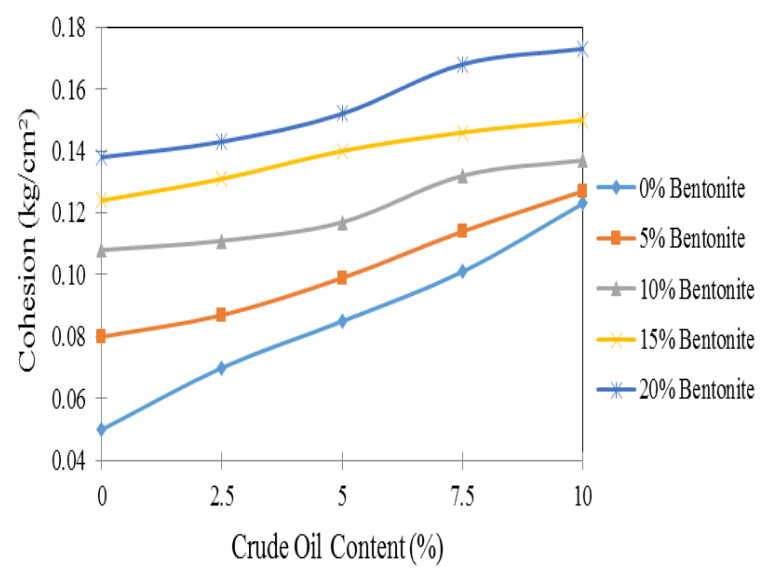

b

Figure 6. Variations of the soil cohesion with a) different levels of oil contamination and b) different bentonite contents

\section{Conclusions}

In this study, the geotechnical behavior of crude oil contaminated sand with different percent of bentonite was investigated through a series of laboratory experiments using standard proctor compaction, direct shear, and consolidation tests apparatus. The conclusions can be drawn as following:

i) By increasing the oil content within the soil, at a specific bentonite content, the maximum dry density increases, and it is achieved in lower water content (i.e. the optimum water content decreases with increasing crude oil content). Similarly, at a fixed contaminant dosage, increasing the bentonite content in the soil leads to increase in soil maximum dry density and the optimum moisture content.

ii) At a specific bentonite content, higher contamination causes lower internal friction angles.

iii) Presence of bentonite and oil pollution in the soil, leads to relatively higher cohesion values than clean sample with $0 \%$ bentonite. This is attributed to inherent viscous nature of the crude oil and cohesive character of the bentonite, with crude oil being more influential when compared at equal bentonite/oil content. 
iv) Higher bentonite contents cause lower $C_{v}$ and void ratio in the soil with same oil content under same pressure.

v) Soil with $20 \%$ bentonite content has an unusual pattern in void ratio versus oil content under constant pressure curves.

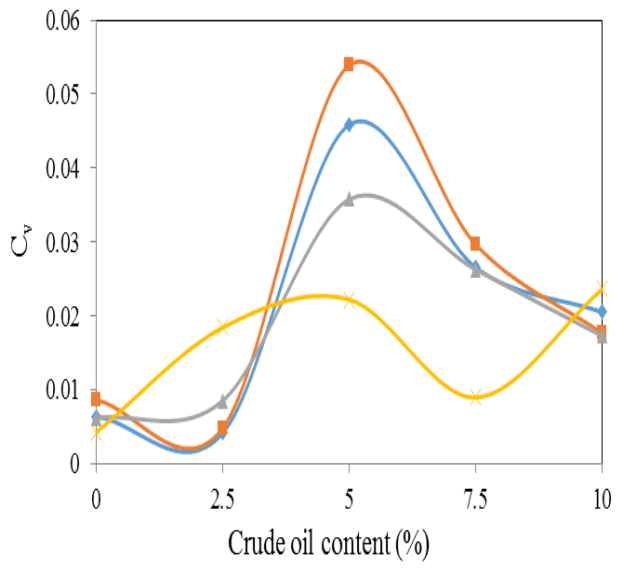

$\mathbf{a}$

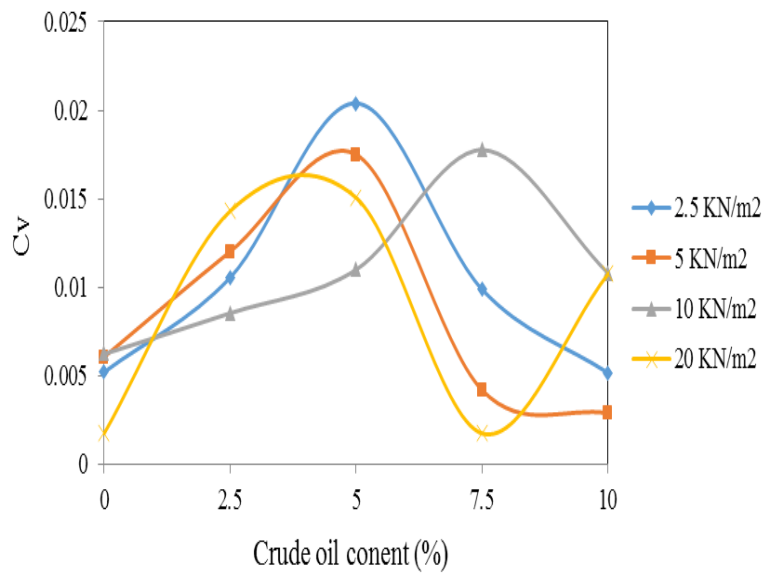

c

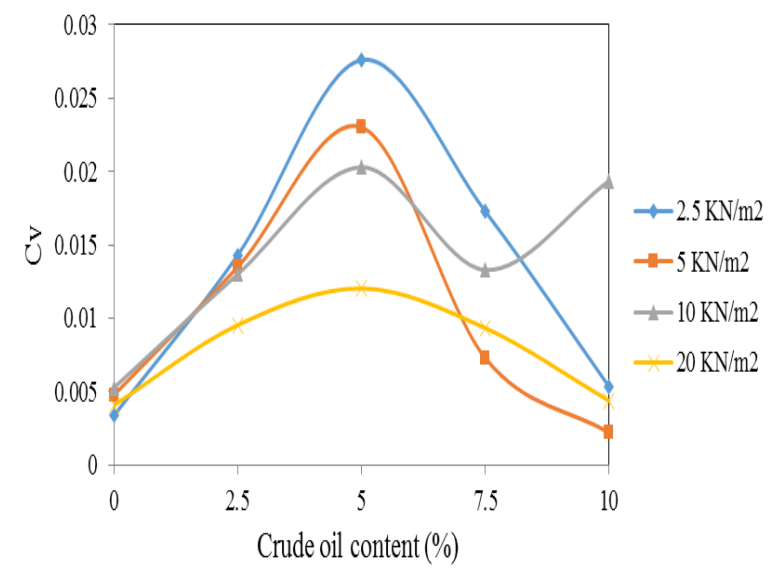

b

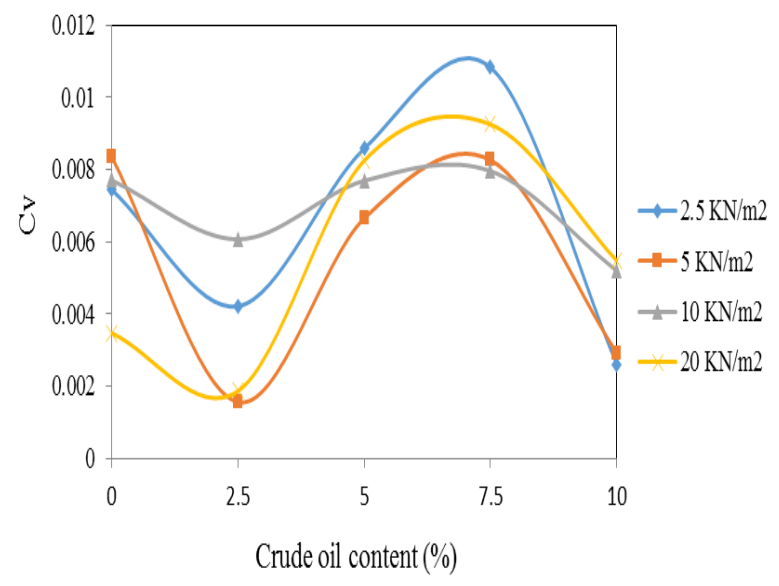

d

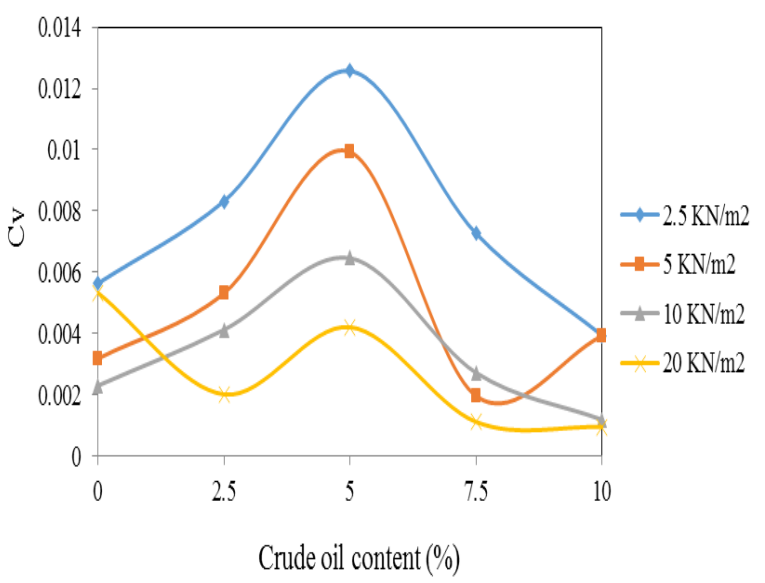

e

Figure 7. Effect of crude oil content on coefficient of consolidation of soil with a) $0 \%$, b) $5 \%$, c) $10 \%$, d) $15 \%$, and e) $20 \%$ bentonite content 


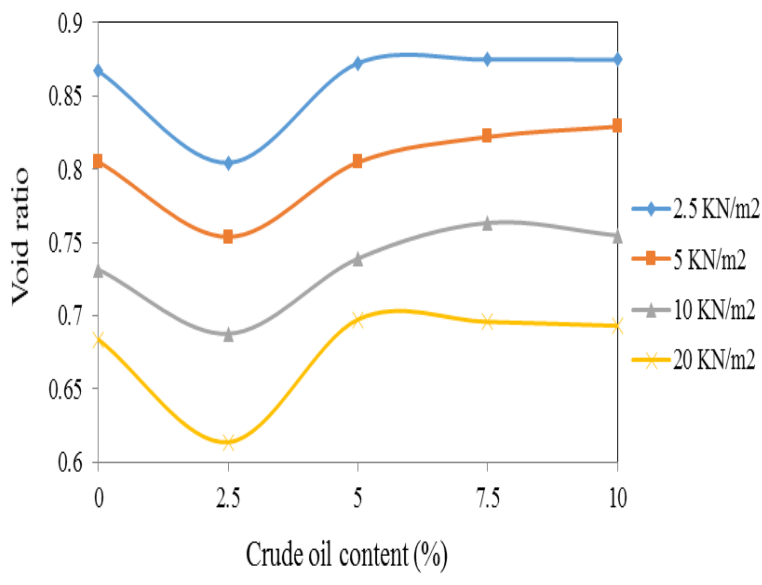

a

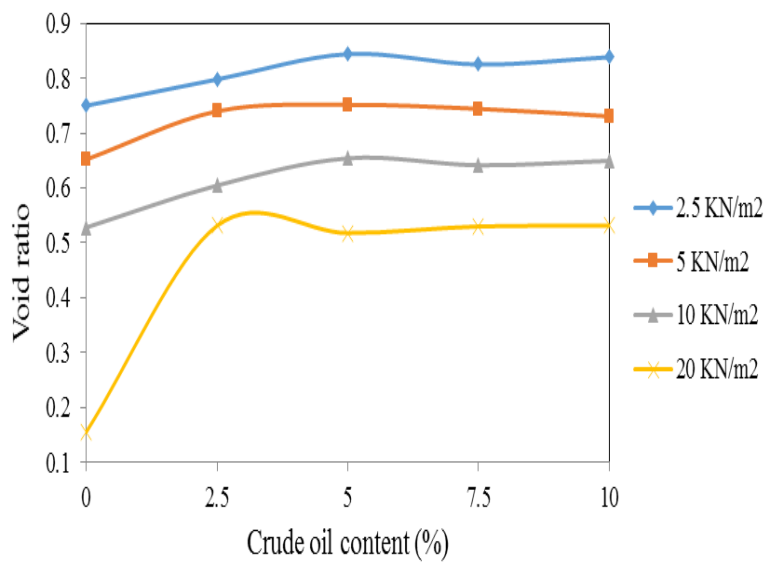

c

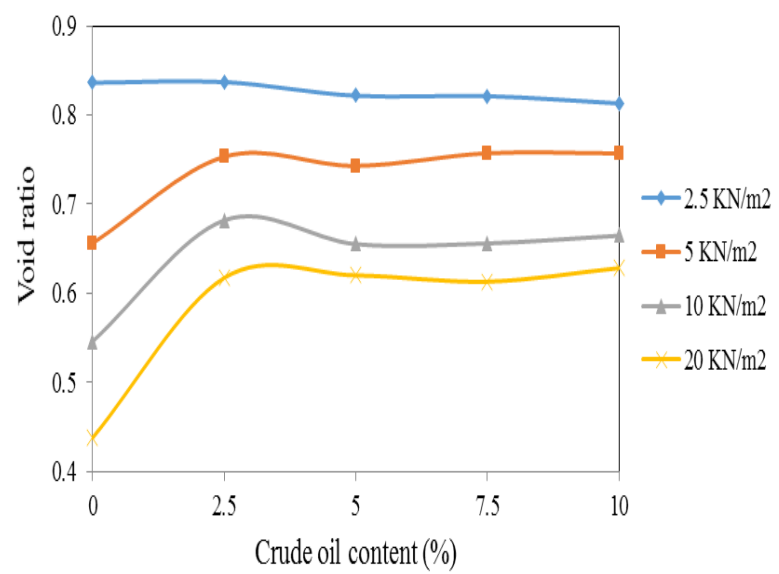

b

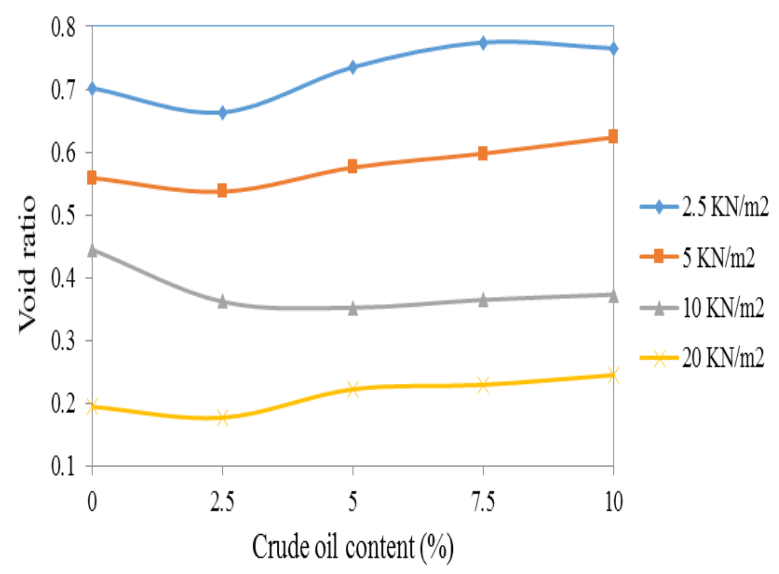

d

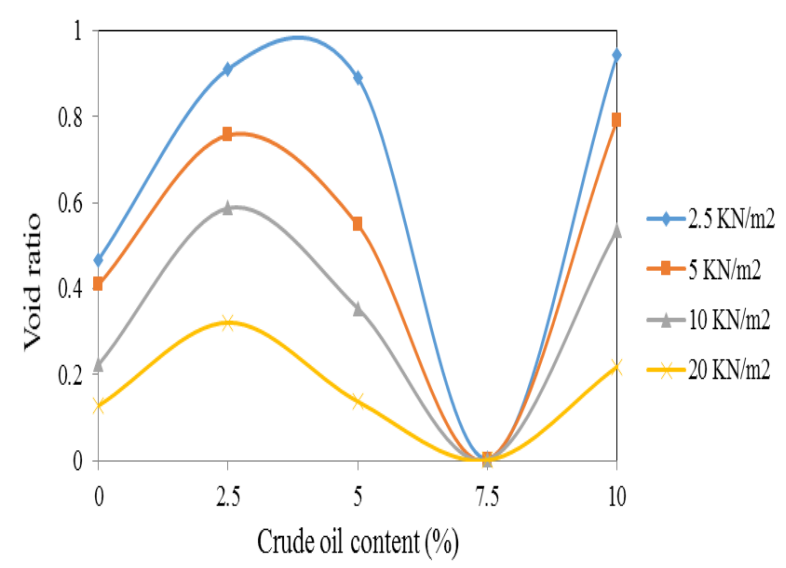

e

Figure 8. Effect of crude oil content on void ratio of soil with a) $0 \%$, b) $5 \%$, c) $10 \%$, d) $15 \%$, and e) $20 \%$ bentonite content

\section{References}

[1] Nazir, A. K. Effect of motor oil contamination on geotechnical properties of over consolidated clay. Alexandria Engineering Journal. 50, 2011, 331-335.

[2] Khosravi, E., Ghasemzadeh, H., Sabour, M.R. and Yazdani, H. Geotechnical properties of gasoilcontaminated kaolinite. Engineering Geology. 166, 2013: 11-16.

[3] Khamehchiyan, M., Charkhabi, A.H. and Tajik, M. Effects of crude oil contamination on geotechnical properties of clayey and sandy soils. Engineering Geology. 89, 2007: 220-229. 
[4] Al-Sanad, H.A., Eid, W.K. and Ismael, N.F. Geotechnical properties of oil contaminated Kuwaiti sand. Journal of Geotechnical and Geoenvironmental Engineering. 121(5), 1995: 407-412.

[5] Rahman, Z.A., Hamzah, U. and Ahmad, N. Engineering geological properties of oil-contaminated granitic and metasedimentary soils. Sains Malaysia 40(4), 2011: 293-300.

[6] Sim, Y.L. and Lee, C.Y. Some geotechnical properties of palm biodiesel contaminated mining sand and weathered granite soil. International Journal of Advanced Scientific Engineering and Technological Research. 1(4), 2012: 1-8.

[7] Rahman, Z.A., Hamzah, U. and Taha, M.R. Influence of oil contamination on geotechnical properties of basaltic residual soil. American Journal of Applied Sciences. 7(7), 2010: 954-961.

[8] Ijimdiya, T.S. The effects of oil contamination on the consolidation properties of lateritic soil. Development and Applications of Oceanic Engineering (DAOE). 2(2), 2013: 53-59.

[9] Ijimdiya, T.S. and Igboro, T. Effect of used oil on the strength and compressibility behavior of lateritic soil. Proceedings of $4^{\text {th }}$ West Africa Built Environment Research (WABER) Conference, Abuja, Nigeria, 2012: 715 723.

[10] http://en.wikipedia.org/wiki/Bentonite, accessed on September 9th, 2015.

[11] Wyszkowska, J., Wyszkowski, M. Role of compost, bentonite and lime in recovering the biochemical equilibrium of diesel oil contaminated soil. Plant Soil Environment, 52(11), 2006: 505-514.

[12] Fu, Y. and Cao, H.J. A new coagulant for spilled oil removal with bentonite and calcium chlorine and sawdust. Advanced Materials Research, 284-286, 2011: 2513-2516.

[13] Talukdar, D. K. and Saikia, B.D. Effect of crude oil on some consolidation properties of clayey soil. International Journal of Emerging Technology and Advanced Engineering, 3, 2013: 117-120.

[14] Moavenian, M.H and Yasrebi, S.S. Effect of organic liquids on one-dimensional consolidation properties of dense clay soils. Seventh Civil Engineering International Congress. 2006 (in Persian).

[15] ASTM D422. Standard test method for particle size analysis of soils. Annual Books of ASTM Standards. 2007.

[16] ASTM D2487. Standard Practice for Classification of Soils for Engineering Purposes (Unified Soil Classification System). Annual Books of ASTM Standards. 2011.

[17] ASTM D854. Standard test method for specific gravity of soils. Annual Books of ASTM Standards. 2002.

[18] ASTM D4253. Standard test methods for maximum index density and unit weight of soils using a vibratory table. Annual Books of ASTM Standards. 2006.

[19] ASTM D4254. Standard test methods for minimum index density and unit weight of soils and calculation of relative density. Annual Books of ASTM Standards. 2006

[20] ASTM D2216. Standard Test Methods for Laboratory Determination of Water (Moisture) Content of Soil and Rock by Mass. Annual Books of ASTM Standards. 2010.

[21] ASTM D698. Standard Test Methods for Laboratory Compaction Characteristics of Soil Using Standard Effort. Annual Books of ASTM Standards. 2007.

[22] ASTM D3080. Standard test method for direct shear test of soils under consolidated drained conditions. Annual Books of ASTM Standards. 1999.

[23] ASTM D2435. Standard Test Methods for One-Dimensional Consolidation Properties of Soils Using Incremental Loading. Annual Books of ASTM Standards. 2011.

(C) 2018 by the author(s). This work is licensed under a Creative Commons Attribution 4.0 International License (http://creativecommons.org/licenses/by/4.0/). Authors retain copyright of their work, with first publication rights granted to Tech Reviews Ltd. 